\title{
Subjectobject and Movementmaterial: A Diffractive Reading of the Becoming of Dance through the Subject
}

Rebecca Yates

\section{ABSTRACT}

\section{ABSTRACT}

I relation till forskningsämnet 'koreografi' önskar jag med denna studie bidra med förståelser för hur interna och externa faktorer bidrar till dansens blivande genom subjektet. Jag vill bistå med förståelser för det multilager av relationer som är pågående i dansens blivande och utveckla förståelser för didaktiska och pedagogiska sammanhang. Genom att studera min egen praxis i en undervisningskontext önskar jag förstå vad som påverkar dansens blivande genom subjektet.

I artikeln använder jag mig till posthumanistiska teorier med utgångspunkt i Rosi Braidottis begrepp, nomadiska subjektet. Det nomadiska subjektet är grundläggande för studien eftersom det använder sig av materialistiska förståelser för världen samtidigt som det inte frånsäger sig subjektets tidigare situerade erfarenheter och förkroppsligade kunskap. Förutom det nomadiska subjektet används begreppen diffraktion, intra-aktion och agens - begrepp som främst har sina rötter hos Karen Barad, även hon posthumanist.

Utifrån posthumanistiska teorier är jag intresserad av vilka agenter som är intrasslade i dansens blivande och vilka hierarkier som påverkar dansens blivande i min praktik. Jag vill se hur de figurerar och se om det är möjligt för dessa hierarkier att nå positioner som är mer antiessentiella.
With this study, which is linked to the research topic of 'choreography', I wish to contribute to our understanding of how internal and external factors are involved in the becoming of dance through the subject. I want to increase our understanding of the multilayered relationships that are ongoing in the becoming of dance and provide and develop understandings for didactical and pedagogical contexts. By studying my own praxis in a teaching context, I want to understand what is involved in the becoming of dance through the subject.

In the article, I use post-humanist theories, with an emphasis on materialists such as Rosi Braidotti and her concept of the nomadic subject. The nomadic subject is fundamental for this study because it uses materialistic understandings of the world without renouncing the subject's previous situational experience and embodied knowledge. In addition to the nomadic subject, I use concepts such as diffraction, intra-action and agents. These concepts have their roots in the theories of Karen Barad, also a post-humanist.

I am interested in what agents are entangled in the process of becoming and what hierarchies are at work within my practice. I want to determine how they figurate and whether it is possible for these hierarchies to reach positions that are more anti-essential. 


\section{Subjectobject and Movementmaterial: A Diffractive Reading of the Becoming of Dance through the Subject \\ Rebecca Yates}

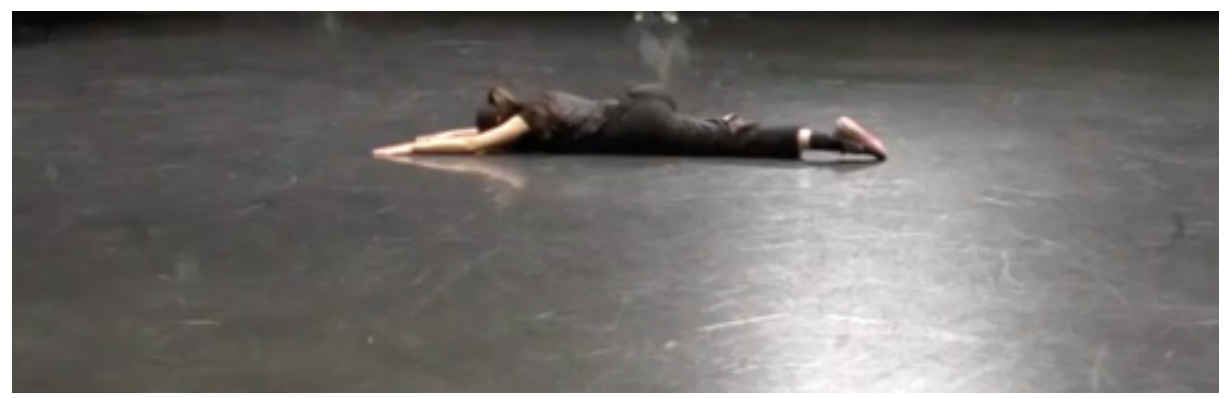

\section{Introduction}

As watery, we experience ourselves less as isolated entities, and more as oceanic eddies: I am a singular, dynamic whorl dissolving in a complex, fluid circulation. [...] Water is between bodies, but of bodies, before us and beyond us, yet also very presently this body, too. [...] What might becoming a body of water _ ebbing, fluvial, dripping, coursing, traversing time and space, pooling as both matter and meaning — give to feminism, its theories, and its practices?

(Neimanis 2012, 96).

During my research and in the process of writing this article, the quote above and the remainder of feminist philosopher Astrida Neimanis's article were very helpful. Her descriptions opened up an understanding of how different parts of my research were connected to, influenced by, and in relation to one another. Neimanis creates an idea of the subject's becoming through bodies, of bodies and in bodies, a metaphor and also an understandable image of how the world is becoming with itself. She uses water to describe how different units are connected to create a phenomenon.

My interpretation of Neimanis' quote is that water is to be seen as the relationship between organs, islands and bodies that together creates a holistic whole.

In this article, I will present the process of my research and formulate the knowledge I have gained investigating my own teaching practice.

\section{My practice as a starting point}

My practice is derived from improvisational methods and choreography in the field of contemporary dance.

Ever since I started my dance training, I have had a somewhat unclear relationship to choreography. I never doubted that choreography was present in my dancing, but I have, at times, felt the need to clarify this for myself. I began to ask myself questions: Where does my dance exist? If I dance, do I choreograph? Where does what I do have value? What is the difference between a pedagogical process and an artistic process? I asked questions regarding the subject's different entities within itself and how we form and are reformed as subjects. 


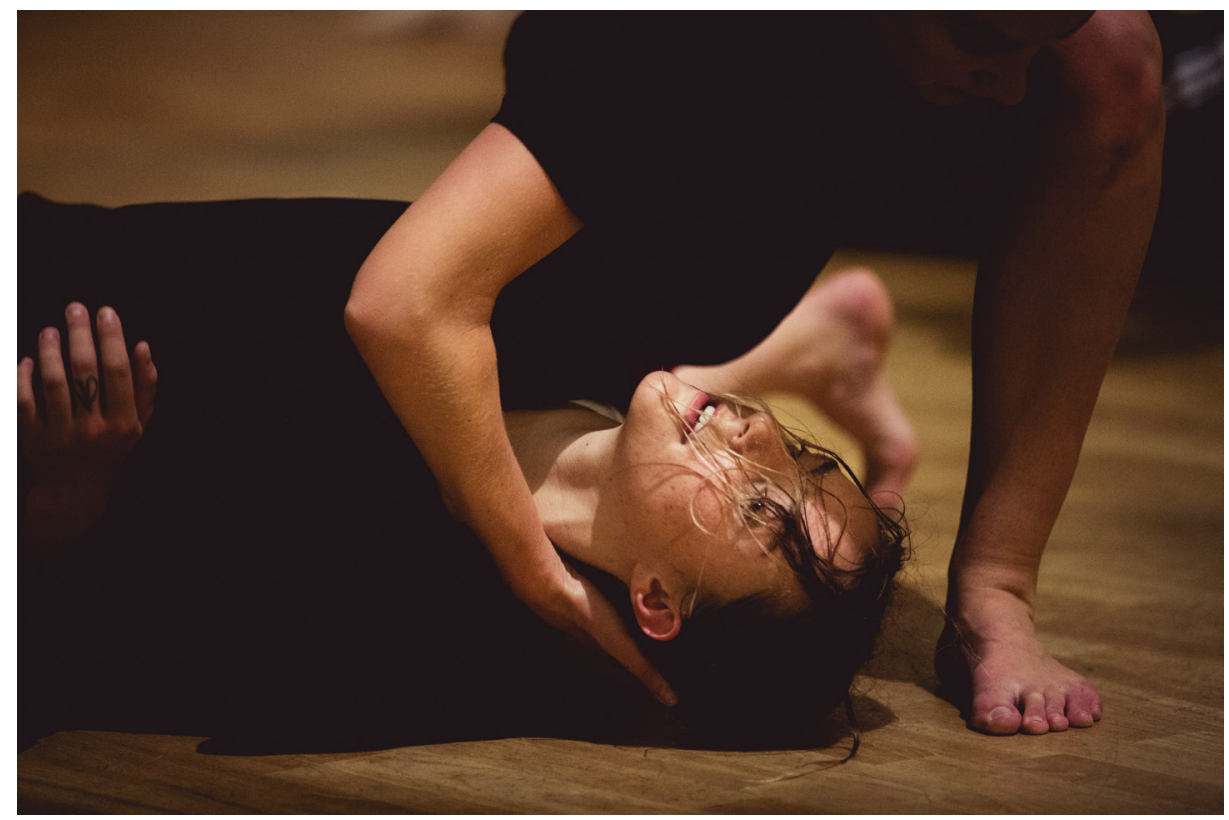

Dans i Blekinge. Foto: Björn Lindberg.

I have had and still have a special interest in feminist perspectives in which embodiment and inscription, as bodily practices, are taken into consideration. Before I began my research, I was becoming more and more interested in theories that untangled or created other ways of seeing dichotomies. When describing dichotomies and hierarchies within dichotomies, I am referring to hierarchies such as body-mind, subject-object and, in some situations, even dancechoreography.

The thoughts above eventually led me to issues that relate to the subject and the becoming processes of dance. The realisation that there is a becoming process of dance in my practice and that dichotomies with preexisting hierarchies might be dictating this practice without me knowing puzzled me. Was I maintaining these hierarchies in my practice? Could I, in that case, make them less static and more anti-essential? In order to investigate how such hierarchies appear in my practice, I decided to scrutinise my teaching and myself as a pedagogue.

\section{The nomadic subject and other materialist concepts}

As a theoretical base for this study, I used Rosi Braidotti's concept the nomadic subject, which she writes about in Nomadic Subjects: Embodiment and Sexual Difference in Contemporary Feminist Theory (2011), as a theoretical base. Braidotti is a philosopher whose theories are at the intersection of social and political theory, cultural politics, gender, feminist theory and ethnicity studies. Apart from the concept nomadic subject, I use understandings derived from Karen Barad, who is a philosopher within the field of materialism. According to Barad in Meeting the Universe Half Way (2007), both material and non-material things, humans and non-humans, have agency. The relationship between different kinds of matter is what creates the understanding of what is becoming (Barad, 91).

The use of Braidotti's nomadic subject concept involves looking at a specific situation and speaking 
from this position. In my research, this process involved in the becoming of dance through the subject of my practice at the specific time studied. The use of the nomadic subject concept allowed me to further analyse the situated, embodied and embedded knowledge that my practice possessed while emphasising relationships. The nomadic subject is a way of seeing alternative subjects and thus reaching beyond the phallogocentric format, as Braidotti describes it. It is important to see alternative subjects because the phallogocentric dictates what has value in our society and therefore excludes other potential subjects $(2011,12,15)$.

Diffraction is a physical phenomenon, but according to Barad, it is also a metaphor for a methodological approach. There are many descriptions of diffraction, but I use the following: «a diffraction pattern does not map where differences appear, but rather maps where the effects of differences appear» $(2007,72,74)$. Agency is about making things happen. In «Co-Choreography and Co-Dramaturgy as Diffraction», dance artist and professor of arts education Tone Pernille Østern uses the example of a chair. She writes that a chair has a strong agency in that it makes us want to sit on it and that agents are productive or performative in terms of creating affect (2017, 46). Affect can be understood as autonomous bodily processes that act directly and regardless of reflection or language (Massumi in Østern 2017, 46). Cartography is a theoretical base and politically informed reading of the present time. Braidotti writes, «As such, it responds to two requirements that are central to my work, namely, to account for one's location in terms both of space (the geopolitical, social, and ecophilosophical dimension) and time (and historical and genealogical dimension» (2011, 4). Intra-action is the relationship between the becoming agents and is relevant to the understanding of how we become in relation to the world (Barad 2007, 140).

\section{Aim and research questions}

The aim of the research was to, through a materialistic perspective, articul ate and contribute to the understanding of the multi-layered relationships ongoing in the becoming of dance through the subject, with the subject meaning the person who is dancing.

Related to the research topic of 'choreography', I wanted to articulate a process in which choreography participates in the becoming of dance through the subject. I also wanted to articulate a contemporary didactic and pedagogical understanding of the becoming of dance in my practice. Both choreography and didactics are, in my research, to be understood as methods in a teaching, as well as artistic processes. To achieve my aim, I asked the following questions:

- Which agents in my practice are active in the becoming of the dance?

- How does dance become through the subject?

\section{Research material}

To study my practice, I chose a week in which I was giving a four-day workshop. The participants were theatre students, most of whom had previous dance experience and a higher education that included dance.

I had a clear structure for my documentation and decided to document two classes per day. I audio-recorded myself directly after each class for approximately 2-3 min and wrote in my journal at the end of each day. I wrote my own thoughts, reflections, things I said and did, students' physical

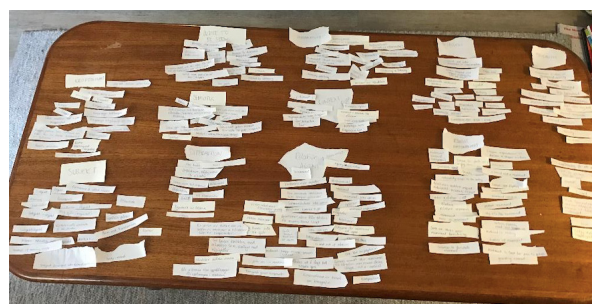

Illustration from thesis (Yates 2019, 47). 
and verbal responses, fragments of phrasings and short descriptions of exercises. I attempted not to judge or reflect on what I documented. I used these two types of documentation because they made me articulate in different ways. For example, I recorded the audio files directly after class, which meant that I still had a sense of being «in the class» when I was documenting. When writing in my journal in the evening, I had more distance from what we had done, and therefore, the reflections had a slightly different tone. There was likely selection involved in what I said and wrote, but I was not aware of it at the time. Both the audio files and journal served as empirical material for my analyses. Below are extracts from my journal.

Allow your eyes to rest and give way to something else. We talk about the collective's being and the occasional absent body. [...] One word, one movement starts and ends simultaneously: one. One becomes more, one becomes a projection. Something that links an inner and an outer physicality-travels out and away, at the same time back again. We look at each other's solos, observing with our eyes, $1 \mathrm{~min}$. The observer then makes the solo. [...] The look is dominant, not just because it sees others. I sometimes remember less when I see.

(Excerpt from journal, Yates 2018).

\section{Method}

In my method, I primarily used diffractive readings, which, for me, meant reading/listening to my journal and audio files many times to determine where differences appear and where I made choices. When listening to the audio files, I wrote down various words and phrases that I had used. Then, I read the journal, underlined words and phrases, and wrote them down on new pieces of paper. Then, I took all the notes with the gathered words and phrases and placed them on the floor in groups depending on affinity.

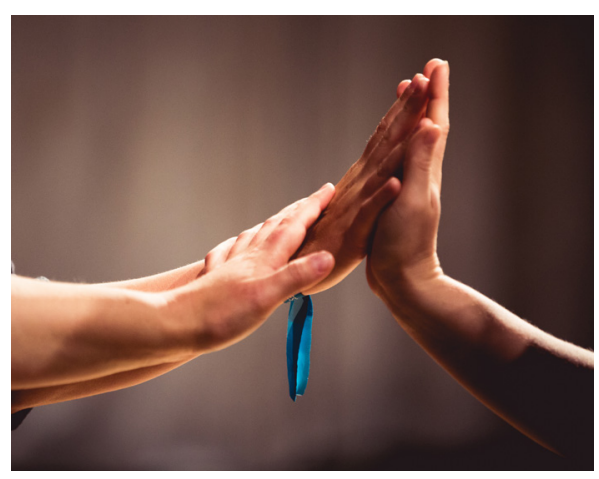

Dans i Blekinge. Foto: Björn Lindberg.

I used Braidotti's principle of the weather map-a cartography $(2011,11)$. My map shows how different areas' contours fade in and out of one another. This was a long process because I tried placing words and phrases in different relationships to one another. Examples of words in the cartography were corporeal, mass is movement, movements, physicality, performativity, choreography, materiality, subject, object and invite to be seen.

The different areas in the cartography could be described as different aspects of my practice. I decided to read the cartography through different insights (subjects, objects, movements, materials and choreography) because these recurred in different areas of the cartography. For me, reading through different insights involves reading the material through, for example, choreography and seeing what is made visible. During this process, I realised that I could not see which agents were the most performative. I needed to understand what my practice was dealing with in a wider sense before I could reach the agents.

After reading through the different insights, I ended up with the words «subject and object» and «movement and material». This because they most clearly, out of all the words and phrases gathered together, defined my practice. They could be found in all areas of the cartography, explained and articulated in different ways. I made an active choice to write 
«subjectobject» and «movementmaterial» together. By writing them together, they become something more than merely words. They expand from their binary division, the hierarchies within, and open up to a broader perspective and understanding.

Through «subjectobject» and «movementmaterial,» I eventually understood which agents were the most performative agents. 'Subjectobject' made visible the agent invite to be seen, and «movementmaterial» visualised choreography and corporeal. They were performative in the sense that they drove the dance to happen, stood out when looking at the cartography, and were present when reading the material through 'subjectobject' and 'movementmaterial.' Most importantly, they were active in the becoming of dance, through the subject of my practice.

\section{Analysis and discussion}

Reading subjectobjects instead of subjects and objects creates an understanding of the relationship between them. I do not necessarily have to be the subject, and the chair is thus not necessarily an object. Instead, I want to allow the relationships between me and the chair or, in this case, the other dancers; the context; the time and the space that we are in, to be in intra-action with one another. The boundary between what is and what becomes a subject and what is and becomes an object thus becomes more diffuse and mobile.

Movementmaterial gives an understanding of the materiality of movement. The definition of the words «movement and material» is «something» that is or has mass, changes shape and moves. This means that movements exist all the time and are tactile, even if this requires microscopic vision, when we consider matter. Matter is present all the time. When something is present and lasting, it is also attributed greater importance and higher status. Matter includes a double meaning: matter as in meaning-making and matter as in mass, or materia (Nationalencyklopedin 2018). The union of these meanings is thus meaningful and moving, which can represent an understanding of dance. In my notes from class, I have written «Mass is movement», which points to a relationship between matter and movement.

Invite to be seen is an agent in the becoming of dance because it allows the subject to invite and meet the viewer and let previous experiences be included in that relationship. Invite to be seen gives permission and offers a state of meeting that allows for relationships to arise. Instead of representations, differences are made visible. Power relations between subject and object

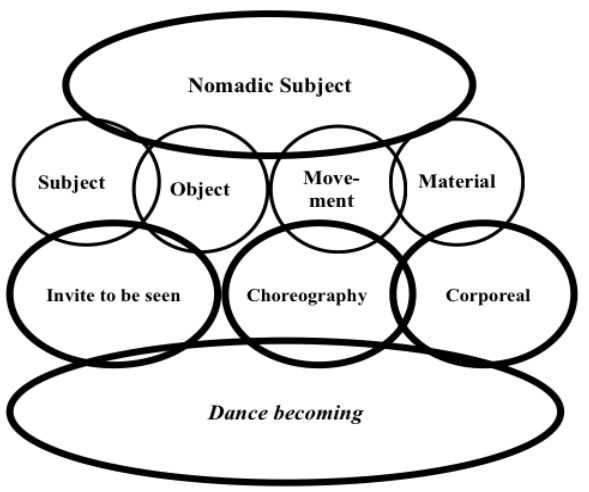

Analysis from thesis (Yates 2019, 32).

become variable and not static states. Invite to be seen can contribute to an openness in the subject, in which the senses are allowed to take place. Invite to be seen is partly about allowing the embodied experiences that are embedded in the subject to be present, and external and internal factors should be allowed to influence the becoming of the dance. Invite to be seen is a movement toward the subject that the subject invites.

In my practice, choreography is part of improvisation, that is, it shapes the improvisation through various exercises and is involved in the becoming of dance. Choosing how the choreography should be before it has taken place gives a different understanding of the becoming process and not the 
one I am interested in in this study. Following the choreography as a participating agent is something else. Choreography is not the goal, but it does affect the dance's becoming. This disrupts the somewhat static relationship I experienced between dance and choreography, in which choreography had a higher status and was the goal. Choreography is the choice of movement, which is expressed through the materiality that makes it possible. It becomes through the body to which it stands in relation. If dance is what becomes, choreography is what happens in the meantime.

Corporeal gives a different understanding of the body's being and becoming and is closely linked to the senses of feeling, hearing, and sight and also to proximity and sensations. These senses provide an understanding of corporeality and shape the materiality and state of corporeality in different ways. At the same time, physicality is associated with the materiality of movement in such a way that it becomes part of the dance. The body is matter or mass and physical. It contains experience and knowledge. The senses unite inner and outer parts of the subject and allow corporeality to reach beyond the contours of the body.

\section{Conclusion}

Throughout my research, the method, analysis and discussion were deeply intertwined. This was, at times, very difficult to understand and even more difficult to write in a way that makes sense. The concept of the nomadic subject helped me to create a cartography of what participates in my practice. Below is a graphic image of my process that I had created by the end of my analysis. Through this image, I could see that even if my practice may be separated in the analysis or text, in practice, everything is connected. This has made me humbler and more open to various processes of becoming.

It is important to clarify that each situation must relate to and emanate from the time and space it exists in at the specific moment, meaning that in other contexts, different from the one I studied, other agents might be active (Braidotti 2011, 5). Braidotti writes that it is the understanding of the present that helps counteract hierarchy production $(2011,6)$. For hierarchies between dichotomies to reach positions that are more mobile and anti-essential is likely unattainable. However, having an understanding of how hierarchies' act is important in making visible other ways of looking at processes and challenging assumptions.

For me, understanding that agents shift relationships depending on context has highlighted the subject's shifting focus in pedagogical and didactic situations. The ability for the subject to actively participate in many relationships at the same time is limited, so the shifting of the agents thus also becomes an understanding of how consciousness of what is taught in the moment shifts.

In relation to choreography, I have sought to provide another understanding of choreography in relation to the becoming of dance. The fact is that choreography participates from within, not as an external structure that dance relates to. Rather, choreography is part of the creation of dance. 


\section{References}

Barad, Karen 2007. Meeting the Universe Half Way:

Quantum Physics and the Entanglement of Matter and Meaning. Durham and London: Duke University Press.

Braidotti, Rosi. 2011. Nomadic Subjects: Embodiment and Sexual Difference in Contemporary

Feminist Theory. 2nd ed. New York Chichester, West Sussex: Columbia University Press.

National Encyklopedin. 2018. Uppslagsverket.

https://www.ne.se/uppslagsverk/.

Neimanis, Astrida. 2012. «Hydrofeminism: Or, On Becoming a Body of Water.» In Undutiful Daughters: Mobilizing Future Concepts, Bodies and Subjectivities in Feminist Thought and Practice, edited by Henriette Gunkel, Chrysanthi Nigianni, and Fanny Söderbäck, 96-115. New York: Palgrave Macmillan.

Østern, Tone Pernille, and Lise Hovik. 2017. «Medkoreografi og med-dramaturgi som diffraksjon [Co-choreography and co-dramaturgy as diffraction].» Journal for Research in Arts and Sports Education, 1 (5): 43-58.

Yates, Rebecca. 2019. «Subjectobject and Movementmaterial: A Diffractive Reading of the Becoming of Dance through the Subject». Master's thesis. Stockholm School of the Arts, School of Dance and Circus.

\section{BIOGRAPHY}

Rebecca Yates is based in the south of Sweden and works as a dancer, choreographer and teacher. Her praxis derives from improvisational methods and choreography in the field of contemporary dance. Rebecca is interested in processes and works where relational aspects and philosophical thoughts are current and allowed to influence the praxis. She holds a bachelor's degree from London Contemporary Dance School and a master's

\section{Images}

Image from exposition of thesis.

Yates, Rebecca. 2019. «Subjectobject and MovementMaterial: A Diffractive Reading of the Becoming of Dance through the Subject.» Stockholm School of the Arts, School of Dance and Circus.

Illustration from thesis.

Yates, Rebecca. 2019. «Subjectobject and Movementmaterial: A Diffractive Reading of the Becoming of Dance through the Subject.» Stockholm School of the Arts, School of Dance and Circus, 47. degree from the DOCH, School of Dance and Circus. This article is based on her master's thesis from the $\mathrm{DOCH}$. The thesis grew from experiencing how various discourses, trainings and concepts stand in hierarchic relation to one another and how they are sometimes experienced as static and therefore dictate aspects of dance practice. yates_rebecca@yahoo.se. 